\title{
Relationship between Pre-service Teachers' University Image Perceptions and Student Loyalty: A Structural Equation Model
}

\author{
Gamze Kasalak $^{1, *}$, Mehmet Özcan², Miray Dağyar ${ }^{1}$ \\ ${ }^{1}$ Faculty of Education, Akdeniz University, Turkey \\ ${ }^{2}$ Faculty of Education, Hacı Bektaş Veli Nevşehir University, Turkey
}

Copyright $\bigcirc 2019$ by authors, all rights reserved. Authors agree that this article remains permanently open access under the terms of the Creative Commons Attribution License 4.0 International License

\begin{abstract}
The purpose of this study is to determine the level of relation between pre-service teachers' university image perception and student loyalty. This research is designed as correlational survey model. University image scale and student loyalty scale are used in this study. Study group consists of 419 pre-service teachers studying at a state university in Turkey who were determined by simple random sampling method. The relations between student loyalty and university image are examined by Pearson correlation coefficients. Structural equation model is constituted to determine whether pre-service teachers' university image perceptions predict university loyalty. According to the descriptive analysis result, pre-service teachers' university image perception related to their universities is at highest level towards quality image and at lowest level towards pleasure image. Besides, among pre-service teachers' student loyalty levels, identification dimension has the highest level compared with self-commitment and determination dimensions. According to the correlation analysis among research variables, moderate level and positive relations are determined among university image perception and student loyalty variables. Path analysis results explain that university image significantly predicts organizational identification, determination and commitment dimensions of student loyalty: the most predicted dimension is commitment and the lowest predicted dimension is organizational identification.
\end{abstract}

Keywords University Image, Student Loyalty, Pre-service Teachers, Higher Education

\section{Introduction}

In history of Turkish education, training teachers has been a crucial problem of the education system since the Ottoman period. Many philosophers who lived in the Ottoman period did studies in education to save the country against collapsing; they offered suggestions related to especially teachers and the teaching profession. For instance, Sat1 Bey (1880-1968), as being a respectable scholar in the field of education, aimed to upgrade the profession to a deserved degree and he tried to change the perception in people's minds that everybody could be a teacher [1]. Similar studies were maintained in order to improve the country in the republic period, too. Village institutions that were active between 1940 and 1954 were put into practice in order to deal with all the problems of the villages and to meet the teacher shortage in the country [2]. The duty of training teachers which was under the control of education institutions that were a branch of ministry of nation education like village institutions or teacher training high schools until 1982 was assigned to Education Faculties of universities in 1982 [8]. As can be seen, in each term of Turkish education, steps have been taken so as to improve the teaching profession because teachers are known to have vital roles in the improvement and the development of the country. In the stage of development of the profession, improvement activities have been made towards the institutions where teachers are trained. The society has high expectations of every prospective teacher in this context. In order for pre-service teachers to be able to fulfill the society's expectations when they start working, faculties of education are supposed to train students in a quality way and with this purpose to fulfill the students' expectations of the university by being able to meet their all socio-cultural needs besides offering a quality education.

In the information era of the 21 st century, the number of the education faculties and the number of the pre-service teachers who study at education faculties have increased in the rapid process of having more universities in Turkey. As 
of 2018, there are 129 public and 72 foundation universities. Active education is carried out in 95 faculties of education that are branches of these universities. According to the higher education statistics of 2017-2018 academic year in these faculties, about 300.000 pre-service teachers are educated at undergraduate degree [59]. In the light of the information given, the factors that affect the quality of the pre-service teachers who can fulfill the society's expectations in terms of quantity need to be examined. Therefore, in order to determine whether the expectations of pre-service teachers from their university and faculty in general are fulfilled or not, it can be important to study the factors, such as the quality of education they get in their institutions, their satisfaction, trust and commitment to the institution, the social facilities of the institution, the social and corporate communications, the initiatives for career planning, the conformity of physical and general conditions, the academic achievements, the national and international perception and the competence of cultural events and facilities. All these factors form the sub-dimensions of pre-service teachers' university image perceptions and student loyalty that are the variables of this research $[5,21 ; 31]$. Finally, in this research, the relationships between the university image perception and student loyalty of pre-service teachers who study at faculty of education have been investigated. Thus, it aims to put forward the effect of image perceptions of pre-service teachers towards the university that they study at on student loyalty by examining the relationships between the variables stated.

When the literature is reviewed, it is seen that foreign based researches that investigate the relationship between the aforementioned variables have been done [3,25, 41]. Alves and Raposo [3] state that school image affects students' loyalty, students' expectations over education and their satisfaction levels. Kheiry et al. [25] said that there is a positive relationship between school image, student satisfaction and student loyalty. Purolinna [41] state that university image affects the student's purpose of enrollment and the number of possible applications to university. The researches carried out in Turkey are seen to be about students' image perceptions towards the universities they study at $[27,13]$ and student loyalty [28]. There are few studies $[2,15]$ in Turkey that investigate the relationship between university image perception and student loyalty. When those studies are examined, it is seen that the sample does not consist of students who study at faculty of education. In addition, this research differs in terms of determining the relationship between variables using the structural equation model. Veenman, Van Hout-Wolters and Afflerbach [53] state that the structural equation models can be used to determine the multifaceted relationships between variables. As a result, since there has not been encountered with a similar research done on pre-service teachers who study at education faculties in Turkey, this research is important in terms of contributing to the literature.

\subsection{Literature Review}

\section{Perceived University Image}

The feelings, thoughts, beliefs and impressions of individuals about objects, individuals and institutions are expressed as 'image'[30]. Treadwell and Harrison [50] define 'image' as the whole of individuals' perceptions about institutions or beliefs about objects. The concept of 'image' at organizational level, on the other hand, is a way that is formed of information, beliefs and emotions which are perceived by the individuals of the organization as a result of the interaction [10] between the members of the organization[49]. Image perception at universities that is one of educational institutions is defined as thoughts about the faculty, curriculum, and education quality and fee relationship by [3]. Kazoleas, Kim and Moffitt [24] base perceived university image on a structure that involves seven dimensions that are quality image, program image, sport image, general view and physical background, social context image, entertainment image and housing and nutrition image. According to this, Kazoleas et al.[24] base quality image on school's educational level, adequacy of academic staff, implementation facilities, general service quality for students, research activities, high quality at education and preparing students for work life; program image on academic program, fine arts program, scientific programs, vocational education, basic undergraduate education, quality of master programs, quality of undergraduate programs; sport image on sporting facilities and sport teams; general outlook and physical infrastructure on campus, buildings in campus, campus size, library and faculty of education; social context image on extra-curricular activities and opportunities to use time efficiently; entertainment image on entertainment opportunities for students and finally food-accommodation image on providing students with various suitable housing and nutrition opportunities. In the researchers' study, it is stated that these image types are in a positive relation with each other.

In literature, there have been various studies regarding the measurement of perceived university image $[35,52]$ and variables that affect perceived university image. William and Moffit [57] stated in their study that perceived image has a large and determining effect on the members of institution. Azoury, Daou and Khoury [9] put forward that history and prestige of university, student life, class and cost-quality balance are the factors that create university image. Wilkins and Huisman [58] studied university image in terms of campus opportunities, communication and education fees variables. In addition, when that perceived university image forms clear, central and permanent effects on the individuals' perception [18] is considered, there are also researches regarding the effect of perceived university image on various variables. When literature is reviewed, 
these variables are stated to be students' purpose to choose applying to the university, student loyalty, student satisfaction, students' expectations and quality of education [3, 25, 37, 41]. Brown and Mazzarol[11] have found out that perceived school image predicts student satisfaction and student satisfaction on the other hand predicts student loyalty.

\section{Student Loyalty}

Student loyalty is defined as "the individual's being in contact with the educational institution during undergraduate education and after graduation" [20]. According to another definition, student loyalty is "the attitude that is formed by cognitive, emotional and behavioral dimensions and that ensures students' being at school and in contact with school after graduating" [19]. That a student starts to have sense of loyalty depends primarily on his/her satisfaction with the school. The level of the student's loyalty perception towards a service taken depends on his/her high performance or low quality after taking education [21].

Student loyalty has three dimensions as "organizational identification", "determination" and "self-commitment" [54]. By saying organizational identification, it is emphasized that students assimilate the institution and see themselves as part of it [54], the individuals feel like belonging to an organization and move together with it [6],they are involved in a specific group emotionally[53] and they are ready to identify themselves in terms of a distinct organization identity[51]. In this context, a student who internalizes organizational identification at a high level is expected to feel belonged to university, to consider himself/herself as part of university, to move together with the institution where he/she studies and to involve in institution emotionally. In addition, it can be stated that students will act more willingly in terms of realizing individual-organizational aims [32]. There are relationships between the variables that are organizational identification and academic achievement, self-discipline [38], school seniority [34], communication skill and school prestige [22]. Meydan and Polat [38] state that the time students spend at school is an effective factor in identification. Var [54] expressed students' thought of choosing the same university again with determination. A student whose determination level is high, it can be stated that his/her social determination level is also high [4]. Finally, by saying self-commitment, sense of belonging to the institution [54] is being told. A student who commits himself/herself highly to his/her university can be expected to see himself/herself as part of the institution and to accept the institution's problems as his/her own problems. He can mention his university by being proud during his education life and try to express the difference of the institution from other universities. He can also continue to maintain his relationships after graduation.

According to Helgesen and Nesset [19], in order to ensure student loyalty, higher education institutions should ensure public funding, new regulations, student mobility and global competition. According to Hennig- Thurau et al. [20], students' loyalty to the school affects the level of participation in class and the quality of school's education positively. Moreover, student loyalty towards the school is formed after graduation brings loyalty behaviors such as providing students at school with job or internship opportunities, coming together with students, being in contact with graduate students, working to increase school's income, participating in competitions in which school teams take part, joining annual school meetings and following the news about the school and so on [39].

Student loyalty has relationship with various variables about educational organizations. For example, variables such as student satisfaction $[3,7,11,29]$, quality of service $[3,33]$, adequacy of educational institution [30], image of educational institution $[3,44]$ and school prestige $[48]$ are shown as the variables that affect student loyalty.

Structural relationships between university image perceptions of pre-service teachers and student loyalty were examined in this research. In the framework of the study, the following questions were sought:

1. Are there significant relations between student loyalty and university image of pre-service teachers?

2. Is the perceived university image of pre-service teachers predicting their loyalty towards their universities significantly?

\section{Methods}

\subsection{Research Model}

This research in which the relationships between pre-service teachers' university image perceptions and student loyalty are put forward has been designed in correlational survey model in order to examine the situation in which a variable is predicted by another variable.

\subsection{Sample}

The study group of the research consists of 419 pre-service teachers, who were determined by simple random sampling method and who study at faculty of education at a state university in Turkey in 2017-2018 academic year and $26,8 \%$ of the pre-service teachers who replied the diagnostic questions are freshman $(n=110)$, $31,5 \%$ are sophomore $(n=129), 30,5 \%$ are junior $(n=125)$ and $11,2 \%$ are senior students(n=46). Additionally, 320 of the pre-service teachers $(76,4 \%)$ are women and 99 of them $(23,6 \%)$ are men. Their GPA is $2,52(\mathrm{SS}=0,60)$. The average number of the absent days they had in the fall term in the aforementioned academic year is $10,03(\mathrm{SS}=7,68)$. As to the data about satisfaction with being a student at 
their university, the highest rate is $65,8 \%$ which is "Yes" and the lowest rate is $34,2 \%$ which is "No".

\subsection{Data Collection Tools}

The data collection tool of this research consists of two parts: Education levels, gender, age, GPA, number of absent days and satisfaction level with being a pre-service teacher at that university of the pre-service teachers are included in the first part. In the second part, there are University Image Scale and Student Loyalty Scale. The ideas taking part in the scale were collected with a 5-pointLikert scale rating as following: (5) Strongly agree (4) Agree (3) Neither agree nor disagree (2) Disagree (1) Strongly disagree.

\subsubsection{University Image Scale (UIS)}

University Image Scale which was developed by Polat[40] in order to determine pre-service teachers' perceptions regarding their higher education institutions' images was used. University Image Scale that was developed by Polat[40] consists of 35 items and 7 dimensions. These seven dimensions were named as quality image, program image, sport image, general outlook and physical infrastructure, social context image, entertainment image and food-accommodating image. Quality image dimension (QI) consists of 9 items (factor loads: 0,42-0,76), program image dimension (PI) has 8 (factor loads: 0,42-0,85), sport image (SI) dimension has 3 (factor loads: 0,82-0,66), general outlook and physical infrastructure dimension (GOPII) has 6 (factor loads: $0,38-0,76$ ), social context image (SCI) dimension has 9 (factor loads: 0,44-0,81), entertainment image (EI) dimension has two (factor loads: 0,80- 0,82) and food-accommodation image (FAI) dimension has 3 (factor loads: 0,57-0,75) items. In addition, in order to adjust the reliability of the scale, Polat[40] determined Cronbach alpha internal consistency coefficients as $\alpha=, 85$ for quality image, $\alpha=, 64$ for program image, $\alpha=, 76$ for sport image, $\alpha=, 72$ for general outlook and physical infrastructure , $\alpha$ $=, 70$ for social context image, $\alpha=, 70$ for entertainment image, $\alpha=, 62$ for food-accommodation image, $\alpha=, 91$ for the integrity of the scale. In this study on the other hand, while Cronbach alpha internal coefficient is 0,957 for all items, internal coefficients according to dimensions are calculated to be 0,$924 ; 0,854 ; 0,816 ; 0,815 ; 0,863 ; 0,746$ and 0,742 respectively.

\subsubsection{Student Loyalty Scale (SLS)}

In order to determine the loyalty of pre-service teachers towards their universities, Student Loyalty Scale (SLS) which was developed by $\operatorname{Var}[44]$ was used. Students Scale (SS) which was developed by $\operatorname{Var}[44]$ consists of 24 items and 3 dimensions. These three dimensions were named as i) organizational identification, ii) determination and iii) self-commitment. Organizational identification dimension consists of 12 (factor loads: 0,54-0,78), determination dimension consists of 6 (factor loads: 0,60-0,74) and self-commitment dimension consists of 6 (factor load: $0,54-0,71$ ) items. $\operatorname{Var}[44]$ found the fit indices of the model obtained as a result of the confirmatory factor analysis as $\left[\chi^{2}=766,34, \mathrm{sd}=249, \mathrm{P}<0,001\right], \mathrm{RMSEA}=0,09, \mathrm{GFI}=$ 0,80 and CFI $=0,96$. In addition, $\operatorname{Var}[44]$ determined Cronbach alpha internal consistency coefficients which he calculated to be able to determine the reliability of the scale as $\alpha=, 92$ for organizational identification (OI), $\alpha=, 84$ for determination (d), $\alpha=, 88$ for self-commitment (SC) and $\alpha$ $=, 94$ for the whole of the scale. In this study, while Cronbach alpha internal consistency coefficients were calculated as 0,939 for all items, they were as 0,$920 ; 0,813$; 0,834 and 0,814 according to the dimensions respectively.

\subsection{Data Collection and Analysis}

Data were collected from pre-service teachers who were studying at a state university between December 2017 and January 2018 by the researchers with the idea that it would increase the researchers' control and provide significant savings in terms of time and finance [12]. The package programs SPSS 13.0 and LISREL 9.2 were utilized for all analyzes. The relation between Student Loyalty Scale (SLS) and University Image Scale (UIS) were examined with Pearson correlation coefficients. Structural equation model was constituted to determine whether pre-service teachers' university image perceptions predict university loyalty. Path analysis was used in order to put forward the cause and effect relationship between the measured and unmeasured variables and to combine measurement errors [46]. It was paid attention to keep RMSEA and SRMS values which were the goodness of fit indices obtained to test structural equation model created in the frame of the study smaller then 0,10 ; NFI, NNFI and CFI values bigger than 0,90 [43]. In addition, that the ratio of the chi-square $\left(\chi^{2}\right)$ fit test to the degree of freedom $\left(\chi^{2} / \mathrm{sd}\right)$ is between 1-5 values (Sumer, 2000) was used as criteria.

\section{Findings}

The arithmetic means, the standard deviation, and Pearson correlation coefficient values regarding the variables about pre-services teachers' perceived university image and student loyalty are shown in Table 1. 
Table 1. Relations among variables $(n=419)$

\begin{tabular}{|c|c|c|c|c|c|c|c|c|c|c|c|c|}
\hline & $\overline{\mathrm{x}}$ & SS & 1 & 2 & 3 & 4 & 5 & 6 & 7 & 8 & 9 & 10 \\
\hline 1. UI-QI & 3,03 & 0,87 & 1 & & & & & & & & & \\
\hline 2. UI -PI & 2,84 & 0,80 &, $751 * *$ & 1 & & & & & & & & \\
\hline 3. UI -SI & 2,97 & 0,97 &, $484 * *$ &, $600 * *$ & 1 & & & & & & & \\
\hline 4.UI- OPBI & 2,91 & 0,87 &, $607 * *$ &, $640 * *$ &, $575 * *$ & 1 & & & & & & \\
\hline 5.UI-SCI & 2,98 & 0,95 &, $644 * *$ &, $653 * *$ &, $526 * *$ &, $676^{* *}$ & 1 & & & & & \\
\hline 6.UI- EI & 2,81 & 1,05 &, $484 * *$ &, $572 * *$ &, $483 * *$ &, $622 * *$ &, $614 * *$ & 1 & & & & \\
\hline 7.UI -BI & 3,02 & 0,98 &, $480 * *$ &, $561 * *$ &, $432 * *$ &, $555^{* *}$ &, $580 * *$ &, $546 * *$ & 1 & & & \\
\hline 8.SL-OI & 3,26 & 0,86 &, $594 * *$ &, $554 * *$ &, $341 * *$ &, $493 * *$ &, $501 * *$ &, $352 * *$ &, $381 * *$ & 1 & & \\
\hline 9. SL -D & 2,82 & 0,88 &, $587 * *$ &, $488 * *$ &, $308 * *$ &, $467 * *$ &, $459 * *$ &, $372 * *$ &, $354 * *$ &, $602 * *$ & 1 & \\
\hline 10. SL-SC & 2,96 & 0,84 &, $636^{* *}$ &, $622 * *$ &, $382 * *$ &, $555^{* *}$ &, $563 * *$ &, $472 * *$ &, $491 * *$ &, $753 * *$ &, $665 * *$ & 1 \\
\hline
\end{tabular}

$* * \mathrm{p}<0,01$

When the means of pre-services teachers' perceived university image are examined, the highest arithmetic mean belongs to quality image dimension $[\overline{\mathrm{x}}=3,03, \mathrm{SS}=0,87]$, on the other hand the lowest arithmetic mean belongs to entertainment image dimension $[\overline{\mathrm{X}}=2,81, \mathrm{SS}=1,05]$. When the means of pre-service teachers' student loyalty are examined, the highest arithmetic mean belongs to organizational identification dimension $[\overline{\mathrm{X}}=3,26, \mathrm{SS}=0,86]$, on the other hand the lowest arithmetic mean belongs to determination dimension $[\overline{\mathrm{X}}=2,82, \mathrm{SS}=0,88]$. When Pearson correlation coefficients among variables are examined, it is seen that there are positive and significant correlations between university image and student loyalty. Quality image has a moderate level and positive relationship with organizational identification $(r=0,594$, $\mathrm{p}<0,01)$, determination $(\mathrm{r}=0,587, \quad \mathrm{p}<0,01)$ and self-commitment $(\mathrm{r}=0,636, \mathrm{p}<0,01)$. Program image has a moderate level and positive relationship with organizational identification $(\mathrm{r}=0,554, \mathrm{p}<0,01)$, determination $(\mathrm{r}=0,488, \mathrm{p}<0,01)$ and self-commitment $(\mathrm{r}=$ $0,622, \mathrm{p}<0,01)$. Sport image has a moderate level and positive relationship with organizational identification $(\mathrm{r}=$ $0,341, \mathrm{p}<0,01)$, determination $(\mathrm{r}=0,308, \mathrm{p}<0,01)$ and self-commitment $(\mathrm{r}=0,382, \mathrm{p}<0,01)$. General view and physical background has a moderate level and positive relationship with organizational identification $(\mathrm{r}=0,493$, $\mathrm{p}<0,01)$, determination $(\mathrm{r}=0,467, \quad \mathrm{p}<0,01)$ and self-commitment $(\mathrm{r}=0,555, \mathrm{p}<0,01)$. Social context image has a moderate level and positive relationship with organizational identification $(\mathrm{r}=0,501, \mathrm{p}<0,01)$, determination $(\mathrm{r}=0,459, \mathrm{p}<0,01)$ and self-commitment $(\mathrm{r}=$ $0,563, \mathbf{p}<0.01)$. Entertainment image has a moderate level and positive relationship with organizational identification $(r=0,352, p<0,01)$, determination $(r=0,372, p<0,01)$ and self-commitment $\quad(\mathrm{r}=\quad 0,472, \quad \mathrm{p}<0,01)$. Food-accommodation image has a moderate level and positive relationship with organizational identification $(\mathrm{r}=$ $0,381, p<0,01)$, determination $(r=0,354, p<0,01)$ and self-commitment $(r=0,491, \mathrm{p}<0,01)$.
Whether pre-service teachers' university image perceptions predict university loyalty was examined with structural equation model in the study. The model developed consists of a structural equation model, which shows the relationships between university image and student loyalty together with dependent and independent measurement models. In the independent measurement model, university image is both a latent external and an independent variable. The dimensions constituting university image (quality, program, sport, general view and physical background, social context, entertainment and food-accommodation image) are the variables that are observed independently. In the dependent measurement model, organizational identification, determination and self-commitment variables that constitute student loyalty dimensions are both latent internal and dependent variables. The variables that are observed dependently are the expressions that constitute student loyalty dimensions as well. In the model, that the external variable, which is pre-service teachers' perceived university image has influences on student loyalty dimensions internal variables.

Fit indices that were obtained according to the results of Path analysis of the study $\left[\chi^{2}=1649,80 ; \mathrm{sd}=431, \mathrm{p}=\right.$ $0,00<0,01 ; \quad \chi^{2} / \mathrm{sd}=3,82 ; \quad \mathrm{RMSEA}=0,082 ; \quad \mathrm{GFI}=0,80$; $\mathrm{AGFI}=0,77 ; \mathrm{NFI}=0,95 ; \mathrm{CFI}=0,97$ and $\mathrm{SRMR}=0,088]$ show that the model is acceptable (Kline, 2005). The values obtained through non-standardized regression matrix, which was done to determine whether the relationships in the first model were significant and the applied t-test is presented in the Table 2.

Table 2. Non-standardized regression matrix and t-test values regarding the structural equation Model 1

\begin{tabular}{llccc}
\hline $\begin{array}{l}\text { Independent } \\
\text { Variables }\end{array}$ & $\begin{array}{l}\text { Dependent } \\
\text { Variables }\end{array}$ & $\begin{array}{c}\beta \\
(\lambda)\end{array}$ & $\mathrm{t}$ & $\mathrm{R} 2$ \\
\hline \multirow{3}{*}{$\begin{array}{l}\text { University } \\
\text { Image }\end{array}$} & $\begin{array}{l}\text { Organizational } \\
\text { Identification }\end{array}$ & 0,73 & $11,84^{* *}$ & 0,54 \\
\cline { 2 - 5 } & Determination & 0,74 & $7,69 * *$ & 0,55 \\
\cline { 2 - 5 } & Self -Commitment & 0,85 & $4,59 * *$ & 0,72 \\
\hline
\end{tabular}

$* * \mathrm{p}<, 01$ 
As a result of the t-test in which paired comparisons were made, the relationships among organizational identification $(\mathrm{t}=11,84 ; \mathrm{p}<0,01)$, determination $(\mathrm{t}=7,69$; $\mathrm{p}<0,01)$ and self-commitment $(\mathrm{t}=4,59 ; \mathrm{p}<0,01)$ were found to be statistically significant (Table 2). University image, which is the independent variable of the first model consists of seven observed variables. The highest determinant of university image is program image $\left(\lambda_{2.1}=\right.$ $0,84)$. This is followed as quality image $\left(\lambda_{1.1}=0,82\right)$, social context image $\left(\lambda_{5.1}=0,79\right)$, general outlook and physical infrastructure $\left(\lambda_{5.1}=0,78\right)$, entertainment image $\left(\lambda_{6.1}=\right.$ $0,68)$, food-accommodation image $\left(\lambda_{7.1}=0,66\right)$ and sport image $\left(\lambda_{3.1}=0,63\right)$ respectively. Pre-service teachers' university image perceptions come up as self-commitment $\left(\lambda_{1.3}=0,85\right)$ at the highest level. This is followed by determination $\left(\lambda_{1.2}=0,74\right)$ and organizational identification $\left(\lambda_{1.3}=0,73\right)$. (Figure 1)

In addition, the explained variance coefficients that show the contribution of university image on student loyalty dimensions ( $\mathrm{R}^{2}$ values) are also presented in Table 2. According to this, all dimensions constituting university image are seen to be self-commitment $\left(\mathrm{R}^{2}=0,72\right)$ with the highest explanation ratio, determination $\left(R^{2}=0,55\right)$ and organizational identification $\left(\mathrm{R}^{2}=0,54\right)$ respectively. In other words, that pre-service teachers commit themselves to their University is explained by $72 \%$, that they follow their universities determinedly (determination) is explained by $55 \%$ and that they identified themselves with their universities is explained by $54 \%$ with their university image perceptions $\left(\mathrm{OI}==0.73^{*} \mathrm{UI}, \mathrm{R}^{2}=0.54 ; \mathrm{D}=0.74^{*}\right.$ $\left.\mathrm{UI}, \mathrm{R}^{2}=0.55 ; \mathrm{SC} 0.85^{*} \mathrm{UI}, \mathrm{R}^{2}=0.72\right)$.

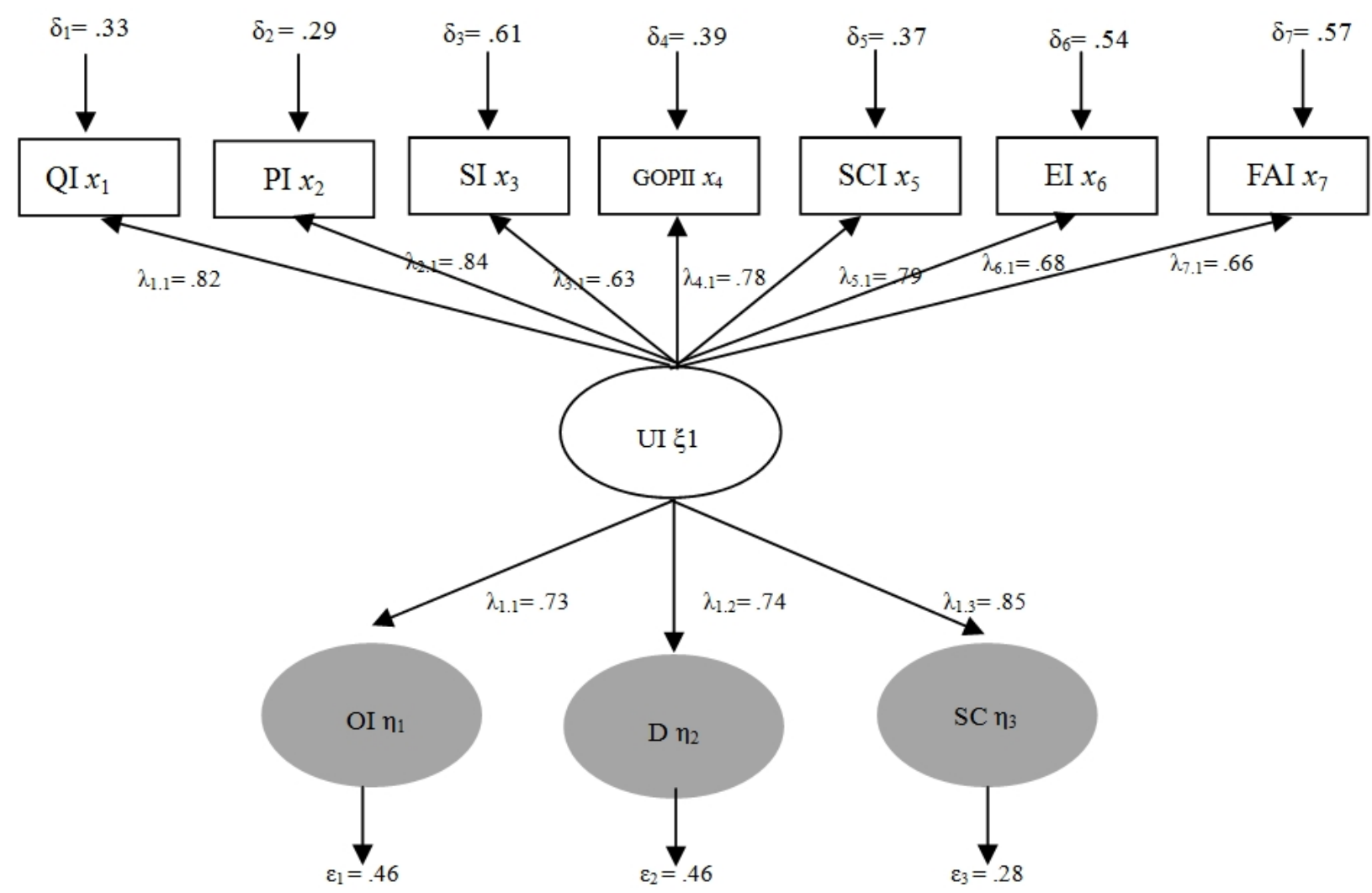

Figure 1. Structural Equation model regarding university image and student loyalty 


\section{Conclusions}

In this study, the relationships between pre-service teachers' university image perceptions and student loyalty were examined via correlational analysis and structural equation model. In addition, the descriptive analysis was used in order to determine the levels of pre-service teachers' university image perceptions and student loyalty dimensions. Findings showed that the perceived university image was an important variable that predicted student loyalty dimensions.

As a result of the descriptive analysis, it was determined that pre-service teachers' university image perceptions were at the highest level in quality image and it was at the lowest level in entertainment image. This result that was obtained overlaps with the ones of [23, 47]. Karacabey et al.[23] stated that students had the highest perceptions of quality and social context image and the lowest perceptions of entertainment image in their study they did on university prep-school students. The findings obtained may result from the fact that since the universities are educational institutions, they make more efforts to fulfill the tasks regarding quality image such as quality of education offered, quality of academicians employed and preparing students for their jobs as the institutional image. Saracel et al.[42] concluded that $47 \%$ of students showed quality level of education as their reason for preferring the university in university preference period in their study they conducted on university's organizational identification. So universities should pay attention to increase the quality of the institution in order to be preferred by students. When other image dimensions in the study were examined, it was concluded that following quality image students perceive food-accommodation, social context, general view and physical background of university at a higher level than program and entertainment images. It can be said that food-accommodation, social context and university's general view and physical background are basic needs that students expect from an institution. Duarte, Alves and Raposo[17] and Arpan et al. [5] stated in their image perception researches towards university students that the most important factors why students' university image perceptions are positive are university's social life, physical environment and professional employment opportunities. In this case, entertainment image can be seen by universities as a dimension that students obtain more easily compared to other dimensions when they wish in their life outside the university as well. Universities organize events that will provide students with a chance to entertain in only some parts of the year or never can stem from the fact that it is thought that entertainment image takes place in the lower rank in increasing the university's image when compared to other dimensions. Taş et al. [47] concluded in their study that education faculty students' program image perceptions were at the "middle" level but it was close to the low level and on the other hand sport and entertainment image were at the low level. In the light of the findings they obtained, they emphasized that universities do not meet students' expectations in terms of sport, entertainment and program and for this reason universities were needed to increase student image by concentrating more on the events and studies in those fields.

According to another finding obtained via the descriptive analysis, it was seen that pre-service teachers' student loyalty images were higher in organizational identification dimension than that of determination and self-commitment. $\operatorname{Var}[54]$ explained the concept of student loyalty as students' and graduates' attitudes towards the university, as students' identification of themselves as part of the institution, their dedication of themselves to the university and its problems and their preference of the same university again if they had a chance. According to the descriptive analysis result of student loyalty dimensions, it can be interpreted that pre-service teachers interiorize their universities, they see themselves as part of the institution, however, and they probably took their departments, namely faculties rather than their universities into consideration in self-commitment and determination dimensions. Students may have a lower perception in self-commitment and determination dimensions because of some reasons such as teaching profession's problems in terms of employment or its low income level [16] by considering the process after graduation.

As a result of the correlational analysis among the variables of the research, there were found to be a moderate level and positive relationships between university image perception and student loyalty. This finding shows that pre-service teachers' university image perceptions are interrelated with their loyalty to their higher education institutions where they study $[1,19]$. That the relationships are at a moderate level and positive shows that universities should pay attention to university image of each student and do studies to improve them in order to provide and keep student loyalty. Today the variety of universities provides students with a chance to prefer universities. It is important for the institution to be a university, which is preferred by students among those ranges of universities. It is seen that managers at higher education institutions should care their universities' image. In line with the significant relationships obtained in the study, structural equation model was constituted in order to reveal the effect of university image on student loyalty in terms of cause and effect relationship. Correlational analysis shows that there is a relationship among the variables; however, it does not provide any data about cause and effect. Here developing a Path model, which examines the structural relationship among the variables and allow to study on dependent and independent variables was thought to be useful in order to reach more descriptive data.

In the research, university image as the independent variable and student loyalty image as the dependent 
variable were used in the structural model, which was constituted to determine the effect of university image on student loyalty. Path analysis results showed that university image significantly predicted organizational identification, determination and self-commitment dimensions that constitute student loyalty and that the most predicted dimension was self-commitment and the least predicted dimension was organizational identification.

In other words, pre-service teachers' image perceptions in terms of the quality of education, educational program, sports, general view and physical background, social context, entertainment and food-accommodation dimensions about the higher education institution where they study explain why pre-service teachers commit themselves to their university (self-commitment), continue their education at their university determinedly (determination) and see themselves as part of the university (organizational identification) respectively. What expectations students may have form a university is explained in terms of the sub-dimensions of university image that was examined in this study. Student loyalty can be reviewed as the commitment of members of each institution including universities to the institution, from this point; student loyalty is accepted as an important purpose for higher education institutions [14]. There are studies which state there is a direct $[19,33,56]$ and indirect [11] relationship between university image and student loyalty in the literature. Alkoç [2] examined the effect of university image and student satisfaction towards their university on student loyalty in his study conducted on university students studying at the Faculty of Economics and Administrative Sciences, and as a result of regression analysis he concluded that student satisfaction, university image and educational program image variables were the determinants of student loyalty. Consequently, as the university image perceptions of university students that reflect their expectations from their universities increase, the levels of identification, self-commitment and determination, which constitute student loyalty will be higher.

The structural equation model, which was developed in the research and examines the effect of university image on student loyalty is thought to make an important contribution to the literature in terms of being conducted in the content of faculty of education, because when the literature was reviewed, no national studies, which examined the relationship among the variables of this research in faculties of education were encountered. Especially those similar studies, which are conducted within the country are foreseen to be beneficial in terms of examining teacher training problems in our country and offering solutions to them. In line with this, student loyalty is needed to be among primary aims of faculties of education because the ones who graduate from faculty of education are known with their teacher identity in the society and they always reflect the institution they graduate from directly in terms of quality and qualification. For this reason, every opportunity that is offered to a pre-service teacher at university can be said to increase the commitment to the institution and to be able to provide the maintenance of student loyalty level after graduation because student loyalty does not only continue during school days but also after graduation. A student who is loyal to his/her school continues to support his/her school materially, verbally and collaboratively after graduation [20]. Köse[31] emphasized that higher education institutions should carry on some studies that would increase student loyalty. He also stated that the studies regarding educational programs' suitability for professional development, increasing the proficiencies of the academic staff, varying social activities in the institution, establishing an alumni association, meeting students' needs and interests and improving physical opportunities should definitely be done by universities. In terms of this, it can be stated that the faculties of education where the students of this research' sample study are established far from the main campus or in rural areas may decrease the students' university image and so their loyalty levels may be affected by this. In the research conducted by Dilşeker [15], which was on students' university image in three different universities, he concluded that the quality of service that the students studying at private universities got was better than that of the students studying at state universities and that university image and loyalty of the ones studying at private universities were at a higher level. That the opportunities affecting university image such as sport facilities, general view and physical background, social context, entertainment and food-accommodation are restricted because of the place where university/faculty is and that the faculty is far from the main campus may affect students' university image perceptions negatively and this case may decrease the student loyalty. Student loyalty levels of pre-service teachers can affect their overall perspectives towards education. For instance, it can be said that a pre-service teacher who internalizes his/her institution's problems will internalize his/her department's problems as well and will even feel responsible to find a solution for the country's problems regarding education. Or a pre-service teacher who has a high level of loyalty towards his/her institution in terms of determination is more likely to utter 'I would choose the same university and the same department if I had a chance to prefer'. It is clear that teachers who do not show any loyalty towards their institution where they study and so do not show any loyalty towards the teaching profession are not beneficial for the educational system, the generations and hence the country.

As a result, whether pre-service teachers' university image predicted student loyalty was investigated in a state university in the context of faculty of education in this research. For this reason, it is impossible to generalize the findings and the research results to all universities and 
faculties of education in the country. It is suggested to conduct similar studies in this topic in different faculties of education as well. In addition, the effect of university image variable on student loyalty was examined in this study. However, it is also possible that there are individual and organizational results, which lead student loyalty to be perceived and which were not examined in this research. It is suggested to test the effects of student loyalty on various individual or organizational results together with the effects of individual or organizational premises on student loyalty for the future researches.

\section{REFERENCES}

[1] Akyüz, Y. (2018). Türk Eğitim Tarihi. Ankara: Pegem Akademi.

[2] Alkoç, Y. K. (2017). Üniversite imaj1, üniversiteye duyulan memnuniyet ve öğrenci sadakati arasındaki ilişkileri anlamaya yönelik bir araştırma. Uluslararası Bilimsel Araştırmalar Dergisi, 2,2, 270-280.

[3] Alves, H. \& Raposo, M. (2010). The influence of university image on student behaviour. International Journal of Educational Management, 24, 1, 73-85.

[4] Aritonang, R. \& Lerbin, R. (2014). Student loyalty modeling. Market-Tržište, 26,1, 77-91.

[5] Arpan, L. M., Raney, A. A. \& Zivnuska, S. (2003). A cognitive approach to understanding university image. Corporate Communications: An International Journal, 8,2, 97-113.

[6] Ashforth, B. E. \& Mael, F. (1989). Social identity theory and the organization, Academy of Management Review,14,1, 20-39.

[7] Austin, A. J. \& Pervaiz, S. (2017). The relation between 'student loyalty' and 'student satisfaction'(A case of college/intermediate students at Forman Christian College). European Scientific Journal, ESJ, 13(3), 100-117.

[8] Azar, A. (2011). Türkiye'deki öğretmen eğitimi üzerine bir söylem: Nitelik mi, nicelik mi. Yükseköğretim ve Bilim Dergisi, 1,1, 36-38.

[9] Azoury, N., Daou, L. \& Khoury, C. E. (2014). University image and its relationship to student satisfaction-case of the Middle Eastern private business schools. International strategic management review, 2,1, 1-8.

[10] Belanger, C., Mount, J. \& Wilson, M. (2002). Institutional image and retention. Tertiary Education and Management, $8(3), 217-230$.

[11] Brown, R. M. \& Mazzarol, T. W. (2009). The importance of institutional image to student satisfaction and loyalty within higher education. Higher Education, 58,1, 81-95.

[12] Büyüköztürk, Ş. (2005). Anket geliştirme. Türk Eğitim Bilimleri Dergisi, 3,2, 133-151.

[13] Cerit, Y. (2006). Eğitim fakültesi öğrencilerinin üniversitenin örgütsel imaj düzeyine ilişkin algıları. Kuram ve Uygulamada Eğitim Yönetimi Dergisi, 12(3), 343-365.

[14] Chandra, T., Ng, Martha.; Chandra, S. \& Priyono (2018). The effect of service quality on student satisfaction and student loyalty: An empirical study. Journal of Social Studies Education Research, 9, 3, 109-131.

[15] Dilşeker, F. (2011). Devlet ve vakıf üniversitelerinde hizmet Kalitesi, öğrenci memnuniyeti, imaj, sadakat ve tavsiye etme arasındaki ilişkinin incelenmesi. Yayımlanmamış yükseklisans tezi. Uşak Üniversitesi, Uşak.

[16] Doğan, I. (2012). Türk eğitim tarihinin ana evreleri. Ankara: Nobel Yayınevi.

[17] Duarte, P. O., Alves, H. B. \& Raposo, M. B. (2010). Understanding university image: A structural equation model approach. International Review on Public and Nonprofit Marketing, 7,1, 21-36.

[18] Dutton, J. E., Dukerich, J. M. \& Harquail, C. V. (1994). Organizational images and member identification. Administrative science quarterly, 39(2) 239-263.

[19] Helgesen , Q. \& Nesset, E. (2007). Images, satisfaction and antecedents: drivers of student loyalty? A case study of a Norwegian university college. Corporate Reputation Review. $10,1,22-38$

[20] Hennig-Thurau, T., Lager, M.F. \& Hansen, U. (2001). Modelling and managing student loyalty: An approach based on the concept of relationship quality. Journal of Service Research, 3(1),331-344.

[21] Hill, F. M. (1995). Managing service quality in higher education: the role of the student as primary consumer. Quality assurance in education, 3(3), 10-21.

[22] Jones, C. \& Volpe, E. H. (2011). Organizational identification: Extending our understanding of social identities through social networks. Journal of organizational behavior, 32(3), 413-434.

[23] Karacabey, M. F., Özdere, M. \&Bozkuş, K. (2016) Üniversite öğrencilerinin örgütsel imaj algıları. Akademik Sosyal Araştırmalar Dergisi, 4 (33), 459-473.

[24] Kazoleas, D., Kim, Y. \& Anne Moffitt, M. (2001). Institutional image: a case study. Corporate Communications: An international journal, 6(4), 205-216.

[25] Kheiry, B., Rad, B. M. \& Asgari, O. (2012). University intellectual image impact on satisfaction and loyalty of students (Tehran selected universities). African Journal of Business Management, 6(37), 10205-10211.

[26] Kline, T. (2005). Psychological testing: A practical approach to design and evaluation. Sage.

[27] Koçak, F. (2014). Öğrenci görüşlerine göre spor öğretimi veren yükseköğretim kurumlarının kurumsal imajı. Ankara Üniversitesi Spor Bilimleri Fakültesi Dergisi, 12 , 1, 71-80.

[28] Korumaz, M. \& Tekel, E. (2016). Yükseköğretimde öğrenci sadakâti ölçeği: Uyarlama, dil geçerliği ve faktör yapısının incelenmesi. Kalem Eğitim veİnsan Bilimleri Dergisi, 7 ,1, 183-203.

[29] Kotler, P. \& Andreasen, A.R. (1996). Positioning the organisation: Strategic marketing for non-profit organisation. 
Toronto: Prentice Hall

[30] Kotler, P. \& Fox, K. F. M. (1995). Strategic marketing for educational institutions. Englewood Cliffs, NJ: Prentice Hall.

[31] Köse, İ. A. (2012). Yükseköğretim kurumlarında öğrenci sadakati. Yükseköğretim ve Bilim Dergisi, 2,2, 114-118.

[32] Leithwood, K. \& Jantzi, D. (1999). Transformational school leadership effects: A replication. School Effectiveness and School Improvement, 10(4) ,451-479.

[33] Lin, W. K., Chiu, C. K. \& TSCI, Y. H. (2008). Modeling relationship quality and consumer loyalty in virtual communities. Cyber Psychology and Behavior, 11(5), 561-564.

[34] Mael, F.A. \& Ashforth, B.E. (1992). Alumni and their alma mater: A partial test of the reformulated model of organizational identification. Journal of Organizational Behaviour, 13,2, 103-123.

[35] Marič, M., Pavlin, J. \& Ferjan, M. (2010). Educational institution's image: A case study. Organizacija, 43,2, 58-65.

[36] Marzo-Navarro, M., Pedraja-Iglesias, M. \& Pilar Rivera-Torres, M. (2005). Measuring customer satisfaction in summer courses. Quality Assurance in Education, 13,1, 53-65.

[37] Masserini, L., Bini, M. \& Pratesi, M. (2018). Do Quality of Services and Institutional Image Impact Students' Satisfaction and Loyalty in Higher Education?. Social Indicators Research, 1-25.

[38] Meydan, C. H. \& Polat, M. (2013). Bir örgüt formu olarak okul ile özdeşleşmede akademik başarı ve özdisiplinin rolü. Eğitim ve Bilim, 38 (167), 27-40.

[39] Osayawe Ehigie, B. \& Taylor, M. (2009). Managing students' loyalty to school after graduation through relationship marketing. The TQM Journal, 21(5), 502-516.

[40] Polat, S. (2011). Üniversite öğrencilerinin örgütsel imaj algıları ile akademik başarıları arasındaki ilişki düzeyi. Kuram ve Uygulamada Eğitim Bilimleri, 11,1, 249-262.

[41] Purolinna, P. (2016). University image and its effect on applying intentions-Case: Aalto University School of Business, Unpublished master thesis, Aalto University.

[42] Saracel, N., Özkara, B., Karakaş, M., Yelken, R., Vatandaş, C., Bayram, K., Alver, K. \& Koçak, H. (2001). Afyon Kocatepe Üniversitesi'nin örgütsel imajı: Afyon halkının üniversiteyi algılaması tutum ve beklentilerine ilişkin araştırma. Afyon: Afyon Kocatepe Üniversitesi Yayınları.

[43] Schermelleh-Engel, K., Moosbrugger, H. \& Müller, H. (2003). Evaluating the fit of structural equation models: Tests of significance and descriptive goodness-of-fit measures. Methods of psychological research online, 8,2, 23-74.

[44] Sembiring, M. G. (2013). Determinants of students' loyalty at Universitas Terbuka. Asian Association of Open Universities Journal, 8,1, 47-59.

[45] Sümer, N. (2000). Yapısal eşitlik modelleri: Temel kavramlar ve örnek uygulamalar. Türk psikoloji yazıları, $3(6), 49-74$.
[46] Sehribanoğlu, S. (2005). Yapısal eşitlik modelleri ve bir uygulaması. Yayımlanmamış yükseklisans tezi, Yüzüncü Y1l Üniversitesi, Van.

[47] Taş, A., Karataş, E. \& Küçükçene, M. (2018). Üniversite öğrencilerinin örgütsel imaj algıları. KEFAD 19 ,2, 1304-1321.

[48] Thomas, S. (2011). What drives student loyalty in universities: An empirical model from India. International Business Research, 4,2, 183-192.

[49] Tom, V.R. (1971). The role of personality and organizational 1mages in the recruiting process, Organizational Behavior and Human Performance, 6, 573-592.

[50] Treadwell, D.F. \& Harrison, T.M. (1994). Conceptualizing and assessing organisational 1mage: model, 1mages, commitment, and communication, Communication Monographs 61, 63-85.

[51] Tüzün, İ. K. \& Çağlar, İ. (2008). Örgütsel özdeşleşme kavramı ve iletişim etkinliği ilişkisi. Journal of Yaşar University, 3(9), 1011-1027.

[52] Uluçay, D.M.T. (2012). Yaşar üniversitesi kurumsal imajının üniversitenin farklı paydaş gurupları tarafindan algılanışı. Yayınlanmamış doktora tezi. Anadolu Üniversitesi, Eskişehir.

[53] Van Dick, R., Wagner, U., Stellmacher, J. \& Christ, O. (2004). The utility of a broader conceptualization of organizational identification: Which aspects really matter?. Journal of Occupational and Organizational psychology, $77,2,171-191$

[54] Var, E. Ç. (2013). Üniversite öğrencilerinde ve mezunlarında öğrenci sadakatini yordayan değişkenlerin yapısal eşitlik modellemesiyle incelenmesi. Yayınlanmamış doktora tezi. Ankara Üniversitesi, Ankara.

[55] Veenman, M. V., Van Hout-Wolters, B. H. \& Afflerbach, P. (2006). Metacognition and learning: Conceptual and methodological considerations. Metacognition and learning, 1,1, 3-14.

[56] Yu,G. B. \& Kim, J. H. (2008). Testing the mediating effect of the quality of college life in the student satisfaction and student loyalty relationship. Applied Research in Quality of life, $3,1,1-21$

[57] Williams, S. L. \& Moffitt, M. A. (1997). Corporate image as an impression formation process: Prioritizing personal, organizational, and environmental audience factors. Journal of Public Relations Research, 9(4), 237-258.

[58] Wilkins, S. \& Huisman, J. (2015). Factors affecting university image formation among prospective higher education students: The case of international branch campuses. Studies in Higher Education, 40(7), 1256-1272.

[59] YÖK (2018). Yükseköğretim Kurulu. Yükseköğretim Bilgi Yönetim Sistemi. Yükseköğretim İstatistikleri. Retrieved from [https://istatistik.yok.gov.tr/] on 15.10.2018. 